\title{
Analisis Beban Kerja Mental Satpol PP Pariwisata Karanganyar
}

\author{
Erni Suparti ${ }^{* 1}$, Resmitha Dian Waruju ${ }^{2}$, Sarah Grasela Laleat ${ }^{3}$ \\ ${ }^{1,2,3}$ Program Studi Teknik Industri, Fakultas Teknik, Universitas Setia Budi \\ Jln. Letjend Sutoyo Mojosongo, Jebres, Surakarta, 57127 \\ Email: ${ }^{* 1}$ ernisuparti071184@gmail.com, ${ }^{2}$ dresmitha@gmail.com, ${ }^{3}$ sarahlaleat@gmail.com
}

\begin{abstract}
Abstrak
Karanganyar, Jawa Tengah merupakan kabupaten yang memiliki banyak destinasi wisata. Misalnya Grojokan Sewu, Candi Sukuh, Candi Cetho, Grojokan Jumog, Bukit Sekipan, dan lain sebagainya. Untuk memberi kenyamanan kepada para pengunjung, Bupati Karanganyar pada bulan Juni 2017 menetapkan 12 orang Satuan Polisi Pamong Praja (Satpol PP) unit Pariwisata. Satpol PP memiliki tugas dan tanggung jawab memberikan rasa aman, nyaman, dan ketentraman kepada setiap wisatawan yang berkunjung. Profesi sebagai Satpol PP tidak hanya menggunakan tenaga fisik, tetapi juga mental. Untuk mengetahui beban kerja mental Satpol PP unit pariwisata Karanganyar, perlu dilakukan analisis. Analisis beban kerja mental dilakukan dengan menggunakan metode NASA-TLX. Metode NASA-TLX merupakan metode pengukuran beban kerja mental dengan mempertimbangkan enam dimensi untuk menilai beban mental. Enam dimensi tersebut antara lain tuntutan mental, tuntutan fisik, tuntutan waktu, kinerja, tingkat frustasi, serta tingkat usaha. Metode Nasa TLX memberikan skor beban kerja mental yang diukur melalui pembobotan dari masing-masing dimensi. Dari pembobotan dapat diketahui aspek paling dominan yang menyebabkan adanya beban mental pekerja. Hasil pengukuran melalui metode NASA TLX diperoleh rata - rata beban kerja mental sebesar 74, 39. Skor ini menunjukkan bahwa beban mental Satpol PP unit pariwisata tergolong berat. Adapun aspek yang paling dominan yang menyebabkan beban kerja mental tinggi yaitu dimensi tuntutan waktu. Oleh karena itu diperlukan perbaikan yaitu dengan menambah anggota Satpol PP unit pariwiata sebanyak 2 orang. Jika ditambah anggota, maka diperoleh rata - rata skor NASA TLX, yaitu sebesar 53,14. Dengan demikian kategori beban kerja mental termasuk sedang sehingga tidak membahayakan.
\end{abstract}

Kata kunci: beban kerja mental, satpol PP, NASA-TLX

\section{PENDAHULUAN}

Beban kerja didefinisikan sebagai kapasitas terbatas seorang pekerja dalam menjalankan tugasnya. Beban kerja yang dialami manusia dapat digolongkan menjadi dua yaitu beban kerja fisik dan beban kerja mental. Beban kerja fisik merupakan beban kerja karena aktivitas penggunaan otot manusia. Sedangkan, beban kerja mental adalah beban kerja karena aktivitas penggunaan otak atau pikiran manusia. Fithri \& Anisa (2017) menyatakan beban kerja yang dialami pekerja harus sesuai dengan kapasitas pekerja tersebut. Apabila beban kerja tidak seimbang, maka dapat menimbulkan berbagai dampak negatif, baik terhadap hasil pekerjaan maupun terhadap kondisi fisik dan psikis pekerja. Oleh karena itu perlu dilakukan pengukuran beban kerja untuk mengetahui apakah beban kerja sesuai dengan kapasitas pekerja atau tidak.

Pengukuran beban kerja mental dapat dilakukan dengan menggunakan metode-metode yang mempertimbangkan aspek-aspek dalam beban kerja mental. 
Tekinfo -- Jurnal Ilmiah Teknik Industri dan Informasi -- 39

Salah satu metode yang dapat digunakan adalah metode NASA-TLX. Metode NASA-TLX merupakan metode pengukuran beban kerja mental dengan mempertimbangkan enam dimensi untuk menilai beban mental. Enam dimensi tersebut antara lain tuntutan mental, tuntutan fisik, tuntutan waktu, kinerja, tingkat frustasi, serta tingkat usaha. Dari enam dimensi akan ditentukan pembobotan dimensi yang paling mempengaruhi kerja, dan dilanjutkan dengan penghitungan skor dari $0-100$ pada setiap skala. Penelitian terkait pengukuran beban kerja mental menggunakan NASA-TLX telah banyak dilakukan. Diniaty (2016) meneliti beban kerja mental karyawan di lantai produksi. Fithri \& Anisa (2017) meneliti beban kerja psikologis dan fisiologis karyawan di industri tekstil. Putri, Tambunan \& Fathimahhayati (2018) menganalisis Pengaruh Shift Kerja terhadap Beban Kerja Mental pada Operator Air Traffic Control (ATC). Muslimah \& Hastuti (2017) melakukan analisis beban kerja mental masinis Kereta Api Prameks. Pada penelitian ini dilakukan analisis beban kerja mental Satpol Pamong Praja Unit Pariwisata Karanganyar.

Karanganyar, Jawa Tengah merupakan kabupaten yang memiliki banyak destinasi wisata. Misalnya Grojokan Sewu, Candi Sukuh, Candi Cetho, Grojokan Jumog, Bukit Sekipan, dan lain sebagainya. Untuk memberi kenyamanan kepada para pengunjung, Bupati Karanganyar pada bulan Juni 2017 menetapkan 12 orang Satuan Polisi Pamong Praja (Satpol PP) unit Pariwisata. Satpol PP memiliki tugas dan tanggung jawab memberikan rasa aman, nyaman, dan ketentraman kepada setiap wisatawan yang berkunjung. Profesi sebagai Satpol PP tidak hanya menggunakan tenaga fisik, tetapi juga mental. Tenaga fisik digunakan untuk berjalan, berlari atau melakukan gerakan-gerakan pada proses pengamanan. Adapun kesiapan mental diperlukan dalam menghadapi orang-orang baru, tekanan dari atasan, pelaku kriminal dan tindakan ketidaknyamanan. Collins \& Gibbs (2003) menyatakan bahwa pekerjaan polisi dianggap sangat menekan karena risiko paparan konfrontasi dan kekerasan pribadi dan keterlibatan sehari-hari dalam berbagai insiden traumatis. Satpol PP unit pariwisata juga bekerja dengan jam kerja yang lain dari pekerja pada umumnya. Mereka bekerja pada saat liburan yang seharusnya merupakan waktu untuk berkumpul dengan keluarga. Hal ini tentu menjadi beban tersendiri bagi anggota Satpol PP unit Pariwisata. Untuk menghindari beban mental yang berlebihan pada Satpol PP unit pariwisata, maka perlu dilakukan pengukuran beban mental.

\section{METODE PENELITIAN}

Metode yang digunakan dalam analisis beban kerja mental dalam penelitian inin adalah metode NASA TLX. Cao et. al (2009) menjelaskan bahwa NASA Task Load Index (TLX) adalah metode yang terkenal untuk mengukur beban mental secara subyektif. Metode ini terdiri dari 6 dimensi untuk menentukan skor beban kerja yang terdiri dari mental demand, physical demand, temporal demand, performance, effort, dan frustration level. Langkah-langkah pengukuran beban kerja mental dengan menggunakan metode NASA-TLX, ialah:

1. Menjelaskan indikator beban mental yang akan diukur. Terdapat 6 dimensi yang akan diukur dalam metode NASA TLX yaitu dijelaskan dalam Tabel 1. 
40 -- Tekinfo -- Jurnal Ilmiah Teknik Industri dan Informasi

Tabel 1 Indikator Beban Kerja Mental

\begin{tabular}{|c|c|c|c|}
\hline Dimensi & Kode & Rating & Keterangan \\
\hline $\begin{array}{l}\text { Mental Demand } \\
\text { (tuntutan mental) }\end{array}$ & MD & $\begin{array}{l}\text { Rendah, } \\
\text { Tinggi }\end{array}$ & $\begin{array}{l}\text { Seberapa besar aktivitas mental dan } \\
\text { perseptual yang dibutuhkan saat } \\
\text { melaksanakan tugas sebagai Satpol PP } \\
\text { Pariwisata } \\
\end{array}$ \\
\hline $\begin{array}{l}\text { Physical Demand } \\
\text { (tuntutan fisik) }\end{array}$ & PD & $\begin{array}{l}\text { Rendah, } \\
\text { Tinggi }\end{array}$ & $\begin{array}{l}\text { Seberapa besar aktivitas fisik } \\
\text { dibutuhkan saat melaksanakan } \\
\text { sebagai Satpol PP Pariwisata }\end{array}$ \\
\hline $\begin{array}{l}\text { Temporal Demand } \\
\text { (tuntutan waktu) }\end{array}$ & TD & $\begin{array}{l}\text { Rendah, } \\
\text { Tinggi }\end{array}$ & $\begin{array}{l}\text { Jumlah tekanan yang berkaitan dengan } \\
\text { waktu yang dirasakan selama } \\
\text { melaksanakan tugas sebagai Satpol PP } \\
\text { Pariwisata. }\end{array}$ \\
\hline $\begin{array}{l}\text { Performance } \\
\text { (performansi/ } \\
\text { kinerja) }\end{array}$ & $\mathrm{P}$ & $\begin{array}{l}\text { Tidak } \\
\text { tepat, } \\
\text { Sempurna }\end{array}$ & $\begin{array}{l}\text { Seberapa besar keberhasilan anggota } \\
\text { Satpol PP Pariwisata di dalam } \\
\text { pekerjaannya, dan seberapa puas dengan } \\
\text { hasil kerjanya. }\end{array}$ \\
\hline $\begin{array}{l}\text { Frustation Level } \\
\text { (tingkat frustasi) }\end{array}$ & FR & $\begin{array}{l}\text { Rendah, } \\
\text { Tinggi }\end{array}$ & $\begin{array}{l}\text { Seberapa besar perasaan tidak aman, putus } \\
\text { asa, tersinggung, serta terganggu sebagai } \\
\text { anggota Satpol PP Pariwisata }\end{array}$ \\
\hline $\begin{array}{c}\text { Effort } \\
\text { (tingkat usaha) }\end{array}$ & $\mathrm{EF}$ & $\begin{array}{l}\text { Rendah, } \\
\text { Tinggi }\end{array}$ & $\begin{array}{l}\text { Seberapa keras kerja mental dan fisik yang } \\
\text { dibutuhkan untuk menyelesaikan } \\
\text { pekerjaan. }\end{array}$ \\
\hline
\end{tabular}

2. Memberikan bobot terhadap masing - masing dimensi. Pembobotan dilakukan melalui responden/ pekerja yang diminta untuk membandingkan dua dimensi yang berbeda dengan metode perbandingan berpasangan. Total perbandingan berpasangan untuk keseluruhan dimensi (6 dimensi) yaitu 15 . Jumlah tally untuk masing-masing dimensi inilah yang akan menjadi bobot dimensi (Widyanti, Johnson, \& de Waard, 2010). Responden diminta memilih salah satu dari tiap - tiap pasangan yang paling dominan menimbulkan beban kerja mental. Hasil pilihan dari responden kemudian direkap sebagai dasar pembobotan. Rincian 15 perbandingan berpasangan ialah sebagai berikut:
- $\mathrm{MD}$--- PD
- $\quad$ MD --- TD
- $\quad \mathrm{MD}$--- $\mathrm{P}$
- $\mathrm{MD}$--- FR
- $\mathrm{MD}$--- EF
- $\quad$ PD --- TD
- PD --- P
- PD --- FR
- $\quad$ PD --- EF
- TD --- P
- TD --- FR
- TD --- EF
- $\quad$ P --- FR
- $\quad \mathrm{P}$--- EF
- $\mathrm{FR}$--- EF 
3. Memberi rating. Peringkat (rating) pada masing-masing deskriptor diberikan skala 1-100, kemudian responden akan memberikan skala sesuai dengan beban kerja yang telah dialami dalam pekerjaannya. Contoh pembobotan pada dimensi pengukuran beban mental:

Seberapa penting kebutuhan mental saat menjalankan tugas sebagai Satpol PP Pariwisata?

$5-10-15-20-25-30-35-40-45-50-55-60-65-70-75-80-85-90-95-$ 100

Seberapa penting kebutuhan fisik saat menjalankan tugas sebagai Satpol PP Pariwisata?

$5-10$ - 15 - 20 - 25 - 30 - 35 - 40 - 45 - 50 - 55 - 60 - 65 - 70 - 75 - 80 - 85 - 90 - 95 100

4. Menghitung nilai produk tiap dimensi. Nilai produk dihitung dengan mengalikan rating dengan bobot faktor tiap dimensi. Dengan demikian diperoleh 6 nilai produk yaitu MD, PD, TD, P, FR dan EF. Rumus nilai produk adalah sebagai berikut:

Produk $=$ rating $\mathrm{x}$ bobot factor

5. Menghitung Weighted Workload (WWL) dengan menjumlahkan semua nilai produk.

WWL atau Total Nilai Produk $=\mathrm{MD}+\mathrm{PD}+\mathrm{TD}+\mathrm{P}+\mathrm{FR}+\mathrm{EF}$

6. Menghitung skor NASA TLX dengan membagi WWL dengan 15.

Skor $N A S A-T L X=\frac{W W L}{15}$

Setelah diperoleh skor NASA - TLX kemudian diinterpretasikan berdasarkan Tabel 2.

Tabel 2. Klasifikasi Beban Kerja Berdasarkan NASA TLX

\begin{tabular}{ll}
\multicolumn{1}{c}{ Kategori } & \multicolumn{1}{c}{ Skala } \\
\hline Sangat Berat & $81-100$ \\
\hline Berat & $61-80$ \\
\hline Sedang & $41-60$ \\
\hline Ringan & $21-40$ \\
\hline Sangat Ringan & $0-20$ \\
\hline
\end{tabular}

\section{HASIL DAN PEMBAHASAN}

\section{Perhitungan Skor NASA-TLX}

Hasil perhitungan skor NASA - TLX dari anggota Satpol PP unit pariwisata Karanganyar ditampilkan pada Tabel 3. Berdasarkan skor yang diperoleh, dapat diketahui bahwa satu responden (20\%) memiliki beban kerja mental sangat berat dan empat responden $(80 \%)$ memiliki beban kerja mentat berat. Hal ini menunjukkan sebagian besar pegawai pada Satpol PP unit pariwisata memiliki beban kerja mental pada tingkat berat. Tugas unit pariwisata yaitu memberikan pelayanan pada masyarakat yang berkunjung di daerah pariwisata Karanganyar. Mereka menjaga keamanan untuk menciptakan rasa aman dan nyaman pada pengunjung.Semua aktivitas tersebut membutuhkan tuntutan mental tinggi dalam pelaksanaan pekerjaannya. 
42 -- Tekinfo -- Jurnal Ilmiah Teknik Industri dan Informasi

Vol. 7 - No. 1; November 2018 
Tabel 3. Perhitungan Skor NASA TLX

\begin{tabular}{|c|c|c|c|c|c|c|c|}
\hline Responden & Dimensi & Bobot & Rating & $\begin{array}{c}\text { Rating } \\
\mathbf{x} \\
\text { Bobot }\end{array}$ & WWL & Skor & $\begin{array}{l}\text { Beban } \\
\text { Kerja }\end{array}$ \\
\hline \multirow{6}{*}{$\begin{array}{c}\text { Demi Dian } \\
\text { Anuraga }\end{array}$} & MD & 0 & 10 & 0 & \multirow{6}{*}{1250} & \multirow{6}{*}{83.3} & \multirow{6}{*}{$\begin{array}{c}\text { Sangat } \\
\text { berat }\end{array}$} \\
\hline & PD & 2 & 80 & 160 & & & \\
\hline & $\mathrm{TD}$ & 1 & 70 & 70 & & & \\
\hline & $\mathrm{P}$ & 4 & 90 & 360 & & & \\
\hline & EF & 3 & 70 & 210 & & & \\
\hline & FR & 5 & 90 & 450 & & & \\
\hline \multirow{6}{*}{$\begin{array}{c}\text { Hury } \\
\text { Kusmini }\end{array}$} & MD & 2 & 80 & 160 & \multirow{6}{*}{1110} & \multirow{6}{*}{74} & \multirow{6}{*}{ Berat } \\
\hline & PD & 1 & 60 & 60 & & & \\
\hline & TD & 4 & 90 & 360 & & & \\
\hline & $\mathrm{P}$ & 0 & 20 & 0 & & & \\
\hline & EF & 5 & 70 & 350 & & & \\
\hline & FR & 3 & 60 & 180 & & & \\
\hline \multirow{6}{*}{$\begin{array}{c}\text { Erma } \\
\text { Handayani }\end{array}$} & MD & 4 & 70 & 280 & \multirow{6}{*}{1090} & \multirow{6}{*}{72.67} & \multirow{6}{*}{ Berat } \\
\hline & PD & 1 & 60 & 60 & & & \\
\hline & TD & 5 & 80 & 400 & & & \\
\hline & $\mathrm{P}$ & 2 & 70 & 140 & & & \\
\hline & $\mathrm{EF}$ & 3 & 70 & 210 & & & \\
\hline & FR & 0 & 20 & 0 & & & \\
\hline \multirow{6}{*}{$\begin{array}{c}\text { Ririn } \\
\text { Setiyowati }\end{array}$} & MD & 3 & 80 & 240 & \multirow{6}{*}{1020} & \multirow{6}{*}{68} & \multirow{6}{*}{ Berat } \\
\hline & PD & 1 & 60 & 60 & & & \\
\hline & TD & 4 & 80 & 320 & & & \\
\hline & $\mathrm{P}$ & 2 & 50 & 100 & & & \\
\hline & $\mathrm{EF}$ & 5 & 60 & 300 & & & \\
\hline & FR & 0 & 20 & 0 & & & \\
\hline \multirow{6}{*}{$\begin{array}{l}\text { Agung } \\
\text { Widodo }\end{array}$} & $\mathrm{MD}$ & 1 & 50 & 50 & \multirow{6}{*}{1110} & \multirow{6}{*}{74} & \multirow{6}{*}{ Berat } \\
\hline & PD & 4 & 90 & 360 & & & \\
\hline & TD & 3 & 80 & 240 & & & \\
\hline & $\mathrm{P}$ & 3 & 60 & 180 & & & \\
\hline & EF & 4 & 70 & 280 & & & \\
\hline & FR & 0 & 10 & 0 & & & \\
\hline
\end{tabular}

\section{Perbandingan Elemen NASA-TLX}

Berdasarkan pengolahan data skor NASA TLX, dapat diketahui aspek mana yang paling dominan, seperti yang ditunjukkan pada Tabel 4. Berdasarkan hasil penjumlahan dan persentase setiap aspek, dapat diketahui bahwa aspek yang paling mempengaruhi besarnya beban kerja mental pada Satpol PP unit Pariwisata yaitu aspek Temporal Demand atau tuntutan waktu yaitu sebesar $24,91 \%$, diikuti oleh aspek effort/usaha, performance/kinerja, mental demand/ tuntutan mental, physical demand/tuntutan fisik, dan frustation level/tingkat frustasi.

Aspek yang paling berpengaruh pada beban kerja mental satpol PP pariwisata adalah temporal demand atau tuntutan waktu yaitu $24,91 \%$. Temporal 
demand menunjukkan jumlah tekanan yang berkaitan dengan waktu yang dirasakan selama melaksanakan tugas sebagai Satpol PP Pariwisata. Jam kerja satpol PP khusus unit pariwisata tidak pasti, ketika anggota unit lain liburan, anggota satpol PP pariwisata harus melaksanakan tugasnya. Tuntutan semakin tinggi saat liburan sekolah atau hari raya keagamaan. Hal ini menimbulkan beban tersendiri bagi para anggotanya.

Aspek effort/usaha menunjukkan peringkat kedua yaitu 24,19\%. Aspek effort menunjukkan seberapa keras kerja mental dan fisik yang dibutuhkan untuk mencapai hasil yang diinginkan. Satpol PP unit pariwisata harus bekerja keras baik mental maupun fisiknya. Mental harus kuat dan berani. Satpol PP pariwisata harus berani melawan kejahatan yang terjadi di tempat wisata, misalnya pencompetan, pencurian, maupun penculikan. Mereka sekaligus harus mengerahkan fisiknya saat melakukan tugasnya. Kadang mereka harus berlari, turun naik tangga, atau berjalan berkeliling untuk memastikan keamanan.

Tabel 4. Perbandingan Elemen Skor NASA TLX

\begin{tabular}{cccc}
\hline Dimensi & Jumlah Skor & Rata-Rata & \% \\
\hline MD & 730 & 146 & 13.08 \\
\hline PD & 700 & 140 & 12.54 \\
\hline TD & 1390 & 278 & 24.91 \\
\hline OP & 780 & 156 & 13.98 \\
\hline EF & 1350 & 270 & 24.19 \\
\hline FR & 630 & 126 & 11.29 \\
\hline
\end{tabular}

\section{Usulan Perbaikan}

Berdasarkan hasil perhitungan skor akhir NASA TLX diketahui bahwa 1 orang pekerja memiliki tingkat beban kerja mental sangat tinggi, dan 4 orang dengan beban kerja mental tinggi. Semua pekerja di Satpol PP unit pariwisata memiliki beban kerja yang tinggi. Adapun faktor dominan yang mempengaruhi skor akhir beban kerja mental berdasarkan kuesioner yang telah disebar yaitu aspek temporal demand dan effort.

Ramadhan, Tama, \& Efranto (2014) melakukan penelitian terkait beban kerja mental untuk menentukan jumlah operator. Ramadhan, Tama, \& Efranto (2014) menyarankan untuk mengurangi beban kerja mental, usulan perbaikan yang diberikan yaitu dengan melakukan penambahan pekerja dengan cara membagi total beban kerja mental dengan jumlah pekerja hingga diperoleh rata rata skor yang tergolong sedang. Dari hasil pembagian tersebut akan diperoleh rata-rata beban kerja. Penambahan pekerja bertujuan untuk mengurangi rata-rata beban kerja mental pekerja. Pada Satpol PP unit pariwisata, penambahan jumlah pekerja dapat dilakukan pada bagian yang memiliki beban kerja mental sangat tinggi dan tinggi.

Dari hasil perhitungan beban kerja mental pada kondisi nyata diperoleh total nilai beban kerja mental yaitu sebesar 371.97 dengan rata-rata beban kerja mental sebesar 74.39 (kondisi 5 orang pekerja). Jika dilakukan penambahan 1 orang pekerja, rata-rata beban kerja mental menjadi 61.99 (berat) dan jika dilakukan penambahan 2 orang pekerja, rata-rata beban kerja mental menjadi 
53.14 (sedang). Hal ini menunjukkan dengan adanya penambahan pekerja akan mengurangi beban kerja mental rata-rata pekerja pada Satpol PP unit pariwisata Kabupaten Karanganyar.

\section{KESIMPULAN}

Berdasarkan skor akhir NASA TLX pada anggota Satpol PP unit pariwisata Kabupaten Karanganyar, diketahui bahwa 20\% pegawai memiliki beban kerja mental yang sangat tinggi, dan $80 \%$ memiliki beban kerja mental tinggi. Aspek yang paling mempengaruhi besarnya beban kerja mental pada Satpol PP unit pariwisata Kabupaten Karanganyar yaitu aspek temporal demand sebesar $24,91 \%$. Adapun aspek berikutnya adalah aspek effort dan performance sebesar 24,19\% dan 13,98\%. Kemudian aspek mental demand, physiccal demand, dan frustration sebesar 13,08\%, 12,54\%, dan 11,29\%. Usulan yang diberikan untuk mengurangi besarnya beban kerja mental pada Satpol PP unit pariwisata Kabupaten Karanganyar yaitu dengan melakukan penambahan pekerja sebanyak 2 orang. Dengan ditambahnya angggota satpol PP sebanyak 2, maka skor NASA TLX berkurang dan masuk dalam kategori beban kerja mental sedang, yaitu sebesar 53,14.

\section{DAFTAR PUSTAKA}

Cao, A., Chintamani, K.K., Pandya, A.K. and Ellis, R.D., 2009, NASA TLX: Software for assessing subjective mental workload, Behavior research methods, 41(1), pp. 113-117.

Collins, P.A. and Gibbs, A.C.C., 2003, Stress in police officers: a study of the origins, prevalence and severity of stress-related symptoms within a county police force, Occupational medicine, 53(4), pp. 256-264.

Diniaty, D.D., 2016, Analisis Beban Kerja Fisik dan Mental Karyawan di Lantai Produksi pada PT Pesona Laut Kuning, Jurnal Sains dan Teknologi Industri, 13(2), pp. 203-210.

Fithri, P. and Anisa, W.F., 2017, Pengukuran Beban Kerja Psikologis dan Fisiologis Pekerja di Industri Tekstil, Jurnal Optimasi Sistem Industri, 16(2), pp. 120-130.

Muslimah, E. and Hastuti, B.D., 2017, Evaluasi Beban Kerja Mental Masinis Kereta Api Prameks dengan Metode RNASA-TLX (Studi Kasus: PT. KAI DAOP 6 Yogyakarta), Prosiding Seminar dan Konferensi Nasional IDEC 2017.

Putri, R.A., Tambunan, W., and Fathimahhayati, L.D., 2018, Analisis Pengaruh Shift Kerja terhadap Beban Kerja Mental pada Operator Air Traffic Control (ATC) dengan Metode NASA-TLX (Studi Kasus: Bandar Udara Internasional X), Tekinfo: Jurnal Teknik Industri dan Informasi, 6(2).

Ramadhan, R., Tama, I.P. and Efranto, R.Y., 2014, Analisa Beban Kerja Dengan Menggunakan Work Sampling dan NASA-TLX untuk Menentukan Jumlah 
46 -- Tekinfo -- Jurnal Ilmiah Teknik Industri dan Informasi

Operator (Studi Kasus: PT XYZ), Jurnal Rekayasa dan Manajemen Sistem Industri, 2(5), pp. 926-973.

Widyanti, A., Johnson, A. and de Waard, D., 2010, Pengukuran Beban Kerja Mental Dalam Searching Task Dengan Metode Rating Scale Mental Effort (RSME), J@ti Undip: Jurnal Teknik Industri, 5(1), pp.1-6. 